DOI: https://doi.org/10.32839/2304-5809/2019-2-66-34

UDC 37.015.3:37.017.92-058.862

Parasiei-Hocher Alina

Institute of Pedagogical Education and Adult Education of the National Academy of Pedagogical Sciences of Ukraine

\title{
RESULTS' ANALYSIS OF THE IMPLEMENTATION OF THE SPIRITUAL DEVELOPMENT PROGRAM OF ORPHAN CHILDREN IN ADULTS AGE
}

Summary. The article analyzes the results of implementing the psychological and pedagogical program of spiritual development of orphans in boarding school. The psychodiagnostic for the study of components of spirituality and spiritual potential of adolescents, data processing and interpretation of research results is determined and characterized. The sample of respondents consisted of adolescent pupils of state care institutions over orphaned children and children deprived of parental care. The purpose and general structure of the program are presented. The quantitative and qualitative results of the molding experiment with statistically significant differences are presented in comparison of the results of the psychodiagnostic study of the control and experimental groups of the subjects studied.

Keywords: spirituality, spiritual development, orphanage, structural components, molding experiment.

Парасей-Гочер А.О.

Інститут педагогічної освіти і освіти дорослих Національної академії педагогічних наук України

\section{АНАЛІЗ РЕЗУЛЬТАТІВ ВПРОВАДЖЕННЯ ПРОГРАМИ ДУХОВНОГО РОЗВИТКУ СИРІТ ПІДЛІТКОВОГО ВІКУ}

\begin{abstract}
Анотація. Оскільки, духовно-моральний розвиток вихованщів закладів інтернатного типу підліткового віку відноситься до категорії найбільш серйозних проблем психолого-педагогічної науки, у статті подано й проаналізовано основні результати впровадження психолого-педагогічної програми духовного розвитку підлітків-сиріт у закладах інтернатного типу. Наведено емпіричні дані, що засвідчили ефективність психолого-педагогічної програми духовного розвитку підлітків-сиріт. Визначений та охарактеризований психодіагностичний інструментарій для дослідження складових духовності (почуттево-емощійного, пізнавального, морально-поведінкового, ціннісно-смислового компонентів та духовного потенціалу) підлітків, обробка даних та інтерпретація результатів дослідження. Вибірка респондентів складалася 3 вихованців підліткового віку 7-8 класів державних закладів опіки над дітьми-сиротами та дітьми, позбавленими батьківського піклування. В процесі духовного розвитку підлітків-сиріт взаємопов'язані компоненти духовності представили основне завдання розробленої програми (почуттево-емоційний - прийняття та усвідомлення унікальності себе та кожної людини; пізнавальний - розвиток пізнавальної активності про внутрішній світ особистості та її місце в світі; морально-поведінковий - формування у підлітків застосовувати отримані знання та самостійно приймати правильні рішення; ціннісно-смисловий - фрормування духовних цінностей, ідеалів та смислів). Наведено кількісні та якісні результати формувального експерименту, а також зафіксовано статистично достовірні відмінності при порівнянні отриманих результатів психодіагностичного вивчення контрольної і експериментальної груп досліджуваних. Отримані результати емпіричного дослідження дозволяють обгрунтувати один із напрямів процесу духовного розвитку особистості, до якого ми відносимо актуалізацію духовного потенціалу підлітків в поетапному формуванні компонентів духовності. Результати дослідження розкривають нові перспективи у вирішенні проблеми процесу духовного розвитку підлітків-сиріт, як з теоретичної точки зору, так і в практичних цілях в пошуку психолого-педагогічних технологій його розвитку.
\end{abstract}

Ключові слова: духовність, духовний розвиток, підліток-сирота, структурні компоненти, фрормувальний експеримент.

The problem setting. Recently, the interest 1 of modern scholars is aimed at studying the problem of social and psychological development of orphans and children left without parental care. The peculiarities of social and mental development of a child under conditions of maternal deprivation in boarding schools, as well as aspects of social orphanhood, social adaptation, preparation for family life, life and professional self-determination, social-pedagogical adaptation in vocational education institutions are also studied. Caring for the personality of children and adolescents, their development and socialization is one of the main tasks of modern society. S. Bech notes that "the conditions of life and education in which the child acquires social experience play a decisive role in their personal and moral development"
[1, p. 256]. Practice's creation of education, development of the personality of orphan children is an actual problem of modern age and pedagogical psychology. For this purpose it is necessary to study the personal characteristics of orphans and the process of their spiritual development in residential institutions.

Analysis of recent research and publications. Analysis of psychological research shows that the study of the concept of "spirituality" and "spiritual development" is devoted to a considerable number of scientific works of Ukrainian researchers G. Ball, I. Bech, M. Boryshevsky, S. Maksimenko, Zh. Matsenko, V. Moskalets, Z. Karpenko, O. Klymishyn, E. Pomitkin, M. Savchin, G. Shevchenko and others. In the writings of foreign psychologists K. Rogers, E. Fromm, K. Jung, and others. 
Specific psychological peculiarities of orphaned children who are raised in institutions of social and pedagogical support, such as parents' deprivation, violations of psychological attachment, slowing pace of mental development, anxiety, egocentrism, weak orientation towards the future, inadequate self-esteem, self-sustainability of behavior and situational thinking. Thus, numerical modern psychological research, devoted to the peculiarities of the development of orphans in the conditions of state institutions of burn, have been reflected in the works of I. Dubrovina, A. Bikova, M. Kondrat'ev, J. Lanageymer, M. Lisina, Z. Mateichik, V. Mukhina, L. Oliferenko, A. Pryhozhan, A. Smirnova, N. Tolstykh, L. Shipitsyna, T. Shulga and others.

The aim of the article is a results' analysis of the implementation of the program of spiritual development of orphaned children in residential institutions.

Presentation of the main material. One of the tasks of the formative stage of our study was the development and testing of a psychological and pedagogical program that would contribute to the spiritual development of orphans - pupils of boarding schools and the study of its effectiveness. The methodological basis of the psychological and pedagogical program was the main provisions of the spiritual and personal approach. Based on the principles of hierarchy (sequencing), positivity and spiritually personal interaction, as an assignment of the program, we made an attempt to introduce the atmosphere of trust, cooperation (teenage psychologist) into the educational process of the institutions of the orphanage type; awareness of the pupils of their uniqueness and every person; cognitive activity; the use of knowledge by adolescents and make decisions on their own. After all, the process of spiritual development of adolescence orphans is associated with the harmonization of their inner world, the "startup" of emotionally-emotional, cognitive, moral-behavioral and value-semantic spheres, actualizing their spiritual potential in the further direction of life's perspective.
For approbation of the developed program of spiritual development of adolescents orphans in residential institutions, control and experimental groups were formed. In total, 48 teenagers participated in the mock experiment, 23 of them entered the experimental group and participated in the developed psychological-pedagogical program, and 25 adolescents entered the control group that did not participate in the training program.

To analyze the results of the implementation of the psychological and pedagogical program "To the New Shores", we used the same psychodiagnostic toolkit used by comparing the indicators of the spiritual development of adolescent orphans with adolescents from families at the stage of the recording experiment, namely:

- Sensory-emotional component: "Diagnosis of emotional and sensory states" (by E. Pomytkin) [3];

- Cognitive component: "What is good and what is bad?" (by L. Frydman) [5];

- Moral and behavioral component: "Diagnosis of moral motivation" (by G. Slipukhina) [4];

- A value-semantic component: a test of semantic orientation (by D. Leont'ev) [2];

- A general indicator of the level of formation (actualization) of the spiritual potential of adolescents: "Spiritual Potential Personality" (by E. Pomytkin) [3].

Using the statistical criterion U-Mann-Whitney (see Table 1), we found out that statistically significant differences $(p>0,05)$ between the control and experimental groups were not recorded before the program was launched.

Consequently, we can assume that at the beginning of the molding experiment, the control and experimental groups on the psychological parameters of the components of spirituality were on the same level.

After implementation in the experimental group of the spiritual development program of orphans, we have carried out a re-diagnosis of pupils of the control and experimental groups. For comparison of two dependent samples, we used methods of mathematical statistics of a nonparametric criterion, namely the Wilcoxon T-criterion. This non-parametric criterion

Comparison of the experimental and control groups before the training

Table 1 (by U-Mann-Whitney criterion)

\begin{tabular}{|l|c|c|c|c|c|}
\hline & $\begin{array}{c}\text { Sensory- } \\
\text { emotional } \\
\text { component }\end{array}$ & $\begin{array}{c}\text { Cognitive } \\
\text { component }\end{array}$ & $\begin{array}{c}\text { Moral and } \\
\text { behavioral } \\
\text { component }\end{array}$ & $\begin{array}{c}\text { Value-semantic } \\
\text { component }\end{array}$ & $\begin{array}{c}\text { The spiritual } \\
\text { potential } \\
\text { of adolescents }\end{array}$ \\
\hline $\begin{array}{l}\text { Statistics } \\
\text { U Mann-Whitney }\end{array}$ & 276,500 & 277,500 & 261,500 & 212,000 & 279,000 \\
\hline $\begin{array}{l}\text { Statistics } \\
\text { W Wilcoxon }\end{array}$ & 601,500 & 602,500 & 537,500 & 488,000 & 555,000 \\
\hline Z &,- 228 &,- 227 &,- 557 & $-1,560$ &,- 176 \\
\hline $\begin{array}{l}\text { Asymptotic } \\
\text { significance }\end{array}$ &, 820 &, 820 &, 577 &, 119 &, 860 \\
\hline
\end{tabular}

The value of the T-Wilcoxon criterion for the experimental group

Table 2

\begin{tabular}{|l|c|c|c|c|c|}
\hline & $\begin{array}{c}\text { Sensory- } \\
\text { emotional } \\
\text { component }\end{array}$ & $\begin{array}{c}\text { Cognitive } \\
\text { component }\end{array}$ & $\begin{array}{c}\text { Moral and } \\
\text { behavioral } \\
\text { component }\end{array}$ & $\begin{array}{c}\text { Value-semantic } \\
\text { component }\end{array}$ & $\begin{array}{c}\text { The spiritual } \\
\text { potential } \\
\text { of adolescents }\end{array}$ \\
\hline $\mathrm{Z}$ & $-4,202^{\mathrm{b}}$ &,$- 690^{\mathrm{b}}$ & $-3,464^{\mathrm{b}}$ & $-3,088^{\mathrm{b}}$ & $-3,563^{\mathrm{b}}$ \\
\hline $\begin{array}{l}\text { Asymptotic } \\
\text { significance }\end{array}$ &, 000 &, 490 &, 001 &, 002 &, 000 \\
\hline
\end{tabular}


is intended for comparison of indicators measured on one and the same sample of the subjects (before and after the formation experiment). The conclusion about the statistical difference of the indicators is made on the basis of the analysis of the empirical value of the criterion: the larger the difference, the lesser the value of the criterion $\mathrm{T}$ (see Table 2).

As we can see from Table 2 below, with statistically significant differences before and after the formation of the experiment, the dynamics of changes in all indicators of the components of spirituality, in addition to the cognitive component of spirituality, was discovered.

At the moment, we will analyze the results of the study on indicators of spirituality components.

Thus, the results of the sensory-emotional component of the spirituality of adolescent orphans before and after the forming part of the experiment in the experimental group of respondents are significant differences.

A high level of actualization of spiritual potential in the emotional-emotional sphere is characteristic of $26 \%$ of adolescents of residential institutions, which indicates the predominance of positive emotional and emotional states among pupils. We observed the active participation of these children in the training program, increasing openness to new lessons and "trials". With each lesson, teenagers seemed more cohesive, even helping friends with exercises. In the process of re-cutting, the children more confidently participated in diagnosing positive emotional-sensory states. Compared to the answers of the first and second sections, we saw a significant increase in such marks on the scale of positive emotional states, such as "harmony", "enthusiasm", "unity", "compassion", "interest", "friendship", "trust". We are glad to reduce such marks on the scale of negative states: "jealousy", "indifference", "doomedness", "hatred". This can be explained by enriching the inner mood with the positive state in everyday life, the ability to empathize and rejoice in each other, to trust.

Regarding the indicators of the average level of development of the sensory-emotional sphere, $57 \%$ of respondents were found, the index decreased by $4 \%$. This also indicates the positive impact of classes with adolescents, such children were the majority. In this case, the adolescents were reluctant to attend classes, episodically showed reluctance to establish a trusting and open interaction with a psychologist. This can be explained by the prolonged stay in residential institutions.

The low level in the sensory-emotional states decreased by $9 \%$ in adolescents in the experimental group, which was $17 \%$ of the pupils. Having analyzed the answers on the scale, unfortunately, these children did not find interest in "Finding treasures from the bottom of the ocean", they were left untrustworthy, confused. Children (who showed a high level) motivated low-level teens to participate in exercises, discussions, but the latter even showed annoyance in relation to the first. We note that even in everyday life this group of children is not interested in additional extra-curricular activities. We assume that these children have experienced a serious mental trauma, therefore their emotional and emotional state indicates a limited range of emotional responses.
In general, we can say that the lessons of psychological and pedagogical training "Treasures from the bottom of the ocean": "Treasures from the bottom of the ocean - pearls of nature" "Who is my neighbor", "Add colors", etc. helped almost all participants to analyze, "feel, live" their feelings and emotions.

Let's see the results' analyze of the diagnostic of the cognitive component before and after the molding experiment.

The high level of development of the cognitive component is characteristic of $61 \%$ of adolescents. These pupils showed themselves to be most knowledgeable about the content of the concepts of spiritual and moral qualities of man, ways of spiritual and moral development and self-improvement. In the discussion, they easily brought life examples of spiritual and moral deeds, could justify the relationship between the spiritual and moral principles of man and his behavior and deeds. Significant difference in the average level of the cognitive component: in the experimental group decreased by $8 \%$, which was $30 \%$ of respondents, and in the control only $2 \%$. There were no significant changes at a low level, which indicates $3 \%$, which indicates the desire of children to cognition and self-knowledge. It should be noted that the results of the cognitive component of the spirituality of teenage orphans showed a high percentage at the stage of the recording experiment. This may indicate that classmates spend hours with the children on moral principles.

We will analyze the indicators of the level of development of spiritual and moral motivation of teenage orphans of the experimental group.

The data show that a high level of spiritual and moral motivation in the moral-behavioral component of spirituality was found in $39 \%$ of adolescents. These are pupils who, in the process of training, were able to cite numerous examples of their behavior in the spiritual and moral aspect, to lead situations of moral choice, volitional decisions. The average level of spiritual and moral motivation has increased by $4 \%$ of adolescents. The low level of moral-behavioral component has decreased significantly - by $13 \%$ of the respondents. This testifies to the desire of adolescents to strive for the best, to reflex their actions, willful decisions.

The obtained quantitative results of the formation of indicators of the value-semantic component of the spirituality of orphaned teenagers also indicate an increase in their level.

Analyzing the results of the formation of the value-semantic component of spirituality in adolescents, we note that in the experimental group, the percentage of adolescents with high levels increased by $12 \%$, but this figure is more than in the control group of adolescents (4\%). The average level (4\%) did not grow significantly. At the same time, the percentage of the low level of the value-semantic component formation in adolescents in the experimental group after the molding experiment significantly decreased: from $30 \%$ to $13 \%$ (17\%), however, there was no change in the control group.

In the comparative characteristics of the preliminary and control diagnostics, we can note an increase in all the indicators of semisilient orientations in the experimental group. Thus, the obtained 
data testify to positive changes in the experimental group, where the indicators for the subclass of the overall indicator of intelligence increased. There were no significant changes in the control group metrics.

As for the indicators of the general level of spiritual potential of orphaned teenagers in the experimental group in residential institutions, they also showed improvement after the implementation of the forming part of the experiment.

By the molding experiment, the levels of spiritual potential are almost identical between the experimental and control groups of the subjects. We track changes in the indicators of the development of spiritual potential in the experimental group. The indicators with a high level (39\%) of the spiritual potential increased by $22 \%$, but the average (57\%) and low (4\%) levels decreased by $4 \%$ and $18 \%$ of the respondent's experimental gurp. It should be noted that the general indicator of the development of spiritual potential with high and intermediate level was shown by almost the same teenagers who had the same results in terms of components of spirituality.

The results of the molding experiment show significant changes in the psychological peculiarities that determine the process of spiritual development in the experimental group of orphans and the lack of statistically significant changes in the indicators of adolescents in the control group.
The obtained data testify to positive changes in the indicators in the experimental group - indicators of a high level of spiritual development have increased more than twice (before the experiment $17 \%$, after $-39 \%$ ).

Consequently, we can state that the differences between the results in the experimental and control groups are statistically significant and confirm the reliability of positive changes.

On the whole, we note that the results of the formative stage of the study suggest that during the work of the psychological and pedagogical program in the process of spiritual development of adolescent orphans in residential institutions there were significant positive changes, which confirms the working hypothesis that the spiritual development of adolescents may develop through activation psychological and pedagogical program aimed at the phased development of the structural components of spirituality.

Conclusions. Thus, the analysis of the results of the molding experiment of the spiritual development of orphans in boarding schools shows that the proposed psychological and pedagogical program affects the phased development of emotionally-emotional, cognitive, moral-behavioral and value-semantic components of spirituality. The training program for the spiritual development of orphaned teenagers can be used in boarding schools by practical psychologists and educators.

\section{References:}

1. Bekh S.D. (2018). Personality on the path to spiritual values: monograph [Osobystist' na shlyakhu do dukhovnykh tsinnostey: monohrafiya]. Kyiv - Chernivtsi : «Bukrek», 296 p.

2. Leont'ev D.A. (2000). The test of sense-oriented orientations [Test smyslozhyznennykh oryentatsyy]. Moscow : Meaning, $18 \mathrm{p}$.

3. Pomitkin E.O. (2015). Spiritual potential of the personality: psychological diagnostics, actualization and development : manual [Dukhovnyy potentsial osobystosti: psykholohichna diahnostyka, aktualizatsiya ta rozvytok : posibnyk]. Kyiv : "The inner world", $144 \mathrm{p}$.

4. Slepukhyna H.V. (2006). Moral development of high school students in the socio-pedagogical process [Nravstvennoe razvytye starsheklassnykov v sotsyal'no-pedahohycheskom protsesse]. Moscow : Moscow Psychological and Social Institute, $188 \mathrm{p}$.

5. Frydman L.M. (2002). Methodology "What is good and what is bad" [Metodyka "Chto takoe khorosho y chto takoe plokho»]. Diagnosis of emotional and moral development. Ed. I.B. Dermanova. SPb., p. 102-103. 